\title{
Efficiency Measurement with Network DEA: An Application to Sustainable Development Goals 4
}

\author{
Deniz Koçak (ib) 1, ${ }^{*}$, Hasan Türe (ib) 1, Murat Atan ${ }^{1}$ \\ ${ }^{1}$ Department of Econometrics, Ankara Hacı Bayram Veli University, Ankara, Turkey
}

\section{ARTICLE HISTORY}

Received: 13 March 2019

Revised: 23 July 2019

Accepted: 18 August 2019

\section{KEYWORDS}

Relational network DEA, Sustainable development goals 4, Educational economy

\begin{abstract}
Education is the core of the factors that improved people for a better lifestyle and increases the level of society' development. Quality education is one of the most vital goals of Sustainable Development Goals (SDGs) due to actualizing these factors. Using relational network data envelopment analysis (DEA), which have three interrelated substages, this current paper computes the educational economy efficiency of the Organisation for Economic Co-operation and Development (OECD) countries bearing in mind the characteristics related to SDGs. The contribution of our study is the use of a novel approach to computing the educational economy efficiency using relational network DEA with GAMS. Even though some interesting differences reveal in the efficiency of the countries, the findings show that countries with high-efficiency scores are clustered around countries like Latvia, Slovenia, and Korea.
\end{abstract}

\section{INTRODUCTION}

Performance evaluation is a crucial phenomenon for countries with regard to determining the current situation and finding an efficient process that ameliorated this situation. The good performance of countries on social, economic and health issues is possible through the acquisition of a quality education that influences directly the lives and sustainable development of human. Well-educated human capital can be considered of the engine of the production process for new discoveries, ideas, development and eventually new value-added productions. In recent years, numerous studies have been examined as a result of the widespread interest in education. The United Nations emphasized that education for all is always an inseparable part of the agendas of both Millennium Development Goals (MDGs) and Sustainable Development Goals (SDGs) (United Nations, 2015). MDGs are expired at the end of 2015. SDGs is a new agenda integrated into MDGs and covering a 15 years period for the post-2015 with 17 goals and 169 interrelated targets in global developments efforts in social, economic and environmental areas (Griggs et al., 2013; Le Blanc, 2015). Quality Education, which is defined as Ensure Inclusive and Equitable Quality Education and Promote Lifelong Learning Opportunities for All, is the fourth goal of SDGs. Besides, SDGs have 10 targets comprising many different features of education, which aimed at educating the people for enhancing their

CONTACT: Deniz Koçak $\square$ deniz.kocak@hbv.edu.tr Department of Econometrics, Ankara Hacı Bayram Veli University, Ankara, Turkey. 
individual well-being and socio-economic status. By 2030, these agendas pave the way of the creation of the societies with strong sustainable education and culture thanks to the effective and functional learning outcomes of these objectives (Hopkins \& McKeown, 2002; Sterling, 2001).

Quality education is a cornerstone that ensures the human's sustainable development. Although the global awareness is existed for the importance of education, more than 265 million children are out of school and $22 \%$ of them are of primary school age and roughly the same number of them as will be out of school (UN, 2018; UNICEF, 2016). As a percentage of GDP, Latvia spends more on primary education than any other Organisation for Economic Co-operation and Development (OECD) country, followed closely by Slovenia and Poland. However, considering the education expenditure to secondary and tertiary education, Denmark takes the first place. Turkey spend the least as a percentage of their GDP on primary and secondary education. The share of public expenditure per student on tertiary education in Korea is also among the lowest, especially at the tertiary level. Estonia located one of the top performers in Programme for International Student Assessment (PISA) followed by Finland and Korea. In the light of these findings, the analysis of the educational economy efficiency of the OECD countries is crucial from the point of view of policymakers, officials and researchers who are concerned with education in both regional or worldwide (Abbott \& Doucouliagos, 2003; Barra, Lagravinese \& Zotti 2018; Worthington, 2001).

While evaluating the educational economy performance of the countries, any study which consider the linkages between substages of education could not be encountered. Besides, the lack of the efficient analysis or metrics in measuring the performance of the countries makes it difficult to carry out the comparisons of the countries. For intend to fill this gap, the efficiency of most OECD countries is measured towards to indicators based on education economics, employment and PISA (Programme for International Student Assessment) data. This measurement gives critical feedback to international studies whether the education system is quality and well design. Besides, an important focus of this study is that a newest developed theory (relational network DEA) is used for this intent. The relational network DEA can assess countries' education performance from a multistage efficiency and effectiveness perspective and further examine their education performance from a multidimensional viewpoint. Unlike previous studies, we not only directly investigate the relationship between inputs and outputs, but also consider the linkages between education substages (primary, secondary, and tertiary) by means of this methodology. Measuring the efficiency at these disaggregated levels is of great importance as it reflects realistically the concept of that education materializes at the student level (Ruggiero, 2006).

The structure of this paper is organized as follows: Section 2 discussed some relevant indicators of the educational economy. Section 3 describes the methodology. Section 4 presents the research findings obtained from running the GAMS codes. The final section presents a brief summary of the results.

\subsection{Literature Review}

Education efficiency assessment has become a core research to understand progress difficulties owing to the education services supported by government almost every country. To this end, different methodological approaches have showed up over the past few decades. Although the efficiency measurement techniques have been applied to many different types of institutions, but the studies on an international framework with whole countries as units of observation are rarely encountered (Afonso \& Aubyn, 2006). These studies have generally concentrated on how to assign educational resource inputs to improve output performance efficiently. Moreover, it is well known that the education expenditure as input (see Afonso et al., 2005; Aubyn, 2003; Ciro \& Garcia, 2018; Gupta \& Verhoeven, 2001; Hanushek \& Kimko, 2000; Lee \& Barro, 
2001), PISA score as output (see Afonso \& Aubyn, 2005; Afonso \& Aubyn, 2006; Aristovnik, 2012; Jafarov \& Gunnarsson, 2008), and employment rate as output (see Afonso \& Aubyn, 2006; Chen \& Wu, 2007; Lavrinovicha et al., 2015) are the important factors of measurement of educational economy efficiency.

Generally, two type of decision making units (DMUs) have been used to assess the level of efficiency with respect to government expenditure on education in these studies. In the first group, the micro education level (university, school etc.) consider as DMUs. Furthermore, the macro level approaches in which countries are selected as DMUs are included in the second group.

There are various studies for assessing the education efficiency at micro level. Ramzi, Afonso and Ayadi (2016) used DEA for reveal the relationship between school resources and student performance. It is find that inefficiency in education was associated with the poverty in the governorates. Kashim et al. (2017) measured the efficiency of a university faculty in Malaysia by using a network DEA model. They selected several inputs including number of academicians (professors, associate professors, senior lecturers, lecturers, foreign academic staff, non-academic staff) and expenses. The outputs included number of graduates (from undergraduate program, master program, and Ph.D. program), publications, grants, main researchers based on different types of grants, expert lecturers, collaboration activities done under MoU/LoI. Qin and Du (2018) applied the network DEA approach to assess the effectiveness of the universities' research and development (R\&D) performance.

Yang et al. (2018) investigated the inefficiency and productivity of Chinese universities, using two-stage network process over the period of 2010-2013. They used R\&D funds, teaching and research staff, and government block funds as input and number of SCI/SSCI publications, the total number of students, patents, and the other intellectual property forms as output in the first stage. In the second stage, the number of patents and other intellectual properties, which is already used as output in the previous stage, and the staff of the application of R\&D outputs and technology services were used as input; total income was used as output.

When viewed from macro level approaches, Afonso and Aubyn (2006) examined the efficiency of expenditure in education for the 25 mostly OECD countries by using a semiparametric model of a two-step DEA/Tobit analysis. PISA scores, education spending per student, number of teachers, and time spent at school were used as input. These indicators are similar to Sylwester (2002) which was revealed the government spends on education encourage income equality and Wasylenko and McGuire (1985) that the government expenditure on education increase the employment rate.

Guironnet and Peypoch (2018) seek an answer how institutional factors affect the productivity of university by using hierarchical DEA following distinctions: urban/rural areas and public/private universities. Ciro and Garcia (2018) emphasized that most discussions have concentrate on the importance of increasing public expenditure on education covers 37 countries. They measured the efficiency of public secondary education expenditure using a twostep semi-parametric DEA methodology. Private spending (\%GDP), and government expenditures (\%GDP per capita) were selected as input in the first model. Furthermore, the enrolment rates and PISA scores were used as outputs; the teacher-pupil ratio was used as input in second model.

It is important to note that PISA scores of the countries are a remarkable indicator in connection with the test is internationally validity. In this context, Aristovnik (2012) used the average data for 1999-2007 period to show that the long-term efficiency measures as the effects of ICT (Information and Communication Technology) are characterized by time lags. The study find 
that ICT had a significant impact on education sector in the selected EU-27 and OECD countries.

\section{METHOD}

\subsection{Relational Network DEA Model}

The relational network DEA model accounts for both the efficiency of a system and the system's interrelated substages. Thus, the drawbacks of the traditional DEA models that neglects of interrelated substages can be eliminated. Besides, the overall steps of the traditional DEA models that are so-called "black box" can been made explicit.

This study uses the relational network DEA model is comprised of a series of three substages under the assumption of the constant return to scale and output-oriented. The fact that the aim is to increase output rather than input reduction in the educational economy efficiency reveals that the output-oriented model is the appropriate tool (Johnes, 2006).

Figure 1 presents the relational network DEA structure with inputs $X_{i}, i=1,2, \ldots, m$, intermediate products $Z_{p}, p=1,2, \ldots, q$ and $T_{l}, l=1,2, \ldots, d$, and outputs $Y_{r}, r=1,2, \ldots, s$.

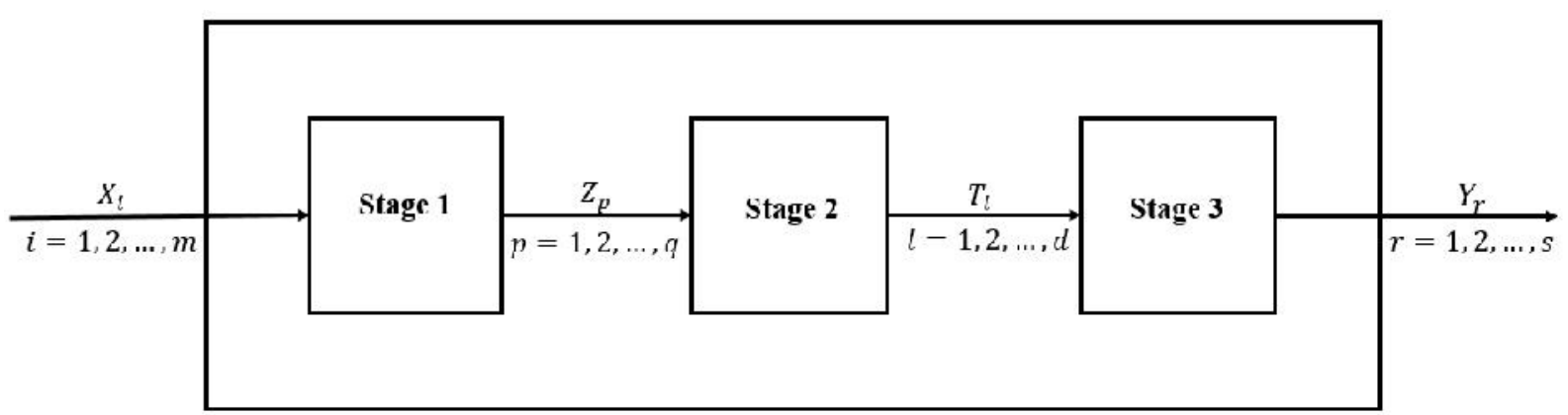

Figure 1. Relational network DEA structure

We define $X_{i}$ and $Y_{r}$ the $i$ th input and $r$ th output of the $j$ th DMU by denoting the $i, r, j$ indexes of input, output and DMU. The intermediate products 1 , which is the outputs of the first stage and the inputs of the second stage, and the intermediate products 2 , which is the outputs of the second stage and the inputs of the third stage, are represented by respectively $Z_{p}$ and $T_{l}$ by denoting the $p, l, j$ indexes of intermediate products 1 , intermediate products 2 and DMU.

The substages efficiency calculated by $E_{k}^{1}, E_{k}^{2}$ and $E_{k}^{3}$, and the overall efficiency of the system can be calculated by $E_{k}=E_{k}^{1} \times E_{k}^{2} \times E_{k}^{3}$. The linear program model of the overall efficiency and its constraint proposed by Kao (2009) is:

$E_{k}=\max _{u_{r}, w_{p}, \gamma_{l}, v_{i}} \sum_{T} u_{T} Y_{r}$

Subject to:

$\sum_{i} v_{i} X_{i i}=1 \forall k$

$\sum_{r} u_{T} Y_{r}-\sum_{i} v_{i} X_{i} \leq 0 \forall j$

$\sum_{l} \gamma_{l} T_{l}-\sum_{i} v_{i} X_{i} \leq 0 \forall j$,

$\sum_{p} w_{p} Z_{p}-\sum_{i} v_{i} X_{i} \leq 0 \forall j$,

$\sum_{r} u_{r} Y_{r}-\sum_{p} w_{p} Z_{p} \leq 0 \forall j$, 
$\sum_{\iota} \gamma_{l} T_{l}-\sum_{p} w_{p} Z_{p} \leq 0 \forall j$,

$u_{T}, w_{p}, \gamma_{l}, v_{i} \geq 0 \quad \forall r, p, l, i$.

The aim of the optimal multipliers $u_{T}, w_{p}, \gamma_{l}, v_{i}$ is unique, in the first instance the overall efficiency namely Model (1) is calculated. Then the efficiencies of the substages must be calculated. In this study, after the measurement of the overall efficiency, the second and third stage will be calculated. With the help of the $E_{k}=E_{k}^{1} \times E_{k}^{2} \times E_{k}^{3}$, the efficiency of the first stage can be obtained as $E_{k}^{1}=E_{k} /\left(E_{k}^{2} \times E_{k}^{3}\right)$. Model (2) shows the linear program of the efficiency of the third stage and its constraint:

$E_{k}^{3}=\max _{u_{r}, w_{p}, \gamma_{l}, v_{i}} \sum_{r-1}^{s} u_{T} Y_{r}$

Subject to:

$\sum_{l=1}^{t} \gamma_{l} H_{j}=1$,

$\sum_{r} u_{T} Y_{r}-E_{k} \sum_{i} v_{i} X_{i}=0 \forall j$,

$\sum_{r} u_{r} Y_{r}-\sum_{i} v_{i} X_{i j} \leq 0 \quad \forall j$

$\sum_{l} \gamma_{l} T_{l}-\sum_{i} v_{i} X_{i} \leq 0 \forall j$,

$\sum_{p} w_{p} Z_{p}-\sum_{i} v_{i} X_{i} \leq 0 \forall j$

$\sum_{r} u_{T} Y_{r}-\sum_{p} w_{p} Z_{p} \leq 0 \forall j$,

$\sum_{\iota} \gamma_{l} T_{l}-\sum_{p} w_{p} Z_{p} \leq 0 \forall j$

$u_{r}, w_{p}, \gamma_{l}, v_{i} \geq 0 \forall r, p, l, i$.

If the first constraint and the objective function of Model (2) is expressed as $\sum_{p=1}^{q} w_{p} Z_{p}=1$ and $\sum_{l=1}^{t} \gamma_{l} T_{l}$, the efficiency of the second stage can be obtained. Otherwise, if the first constraint and the objective function of Model (2) is expressed as $\sum_{i=1}^{m} v_{i} X_{i i}=1$ and $\sum_{l=1}^{t} w_{p} Z_{p}$, the efficiency of the first stage can be obtained.

\subsection{Data}

In this study, the data that express the sub-objectives of the SDG 4 and can be used to measure the educational economy efficiency of the OECD countries are taken into consideration. The 30 OECD countries are the DMUs in the analysis. Besides, the inputs, intermediate products and outputs of the network structure are expressed as Table 1:

Table 1. The inputs, intermediate products and outputs ${ }^{\dagger}$.

\begin{tabular}{cll}
\hline$X_{1}:$ & Government expenditure per primary student (\% of GDP per capita) & $2013-14$ \\
$Z_{1}:$ & PISA science performance (mean) & 2015 \\
$Z_{2}:$ & Government expenditure per secondary student (\% of GDP per capita) & $2013-14$ \\
$T_{1}:$ & Employment rate for upper secondary level (\% of 25-64 year-olds) & $2013-15$ \\
$T_{2}:$ & Government expenditure per tertiary student (\% of GDP per capita) & $2013-14$ \\
$Y_{1}:$ & Employment rate for tertiary level (\% of 25-64 year-olds) & $2013-15$ \\
\hline
\end{tabular}

These indicators based on the levels defined by International Standard Classification of Education (ISCED) are taken are will be used in the substages of the network structure. The

${ }^{+}$The data that cover 2013-2015 period were collected from the database of OECD. 
reason is that these standard international education levels provide unity for measuring the performance of the students (Johnes et al., 2017). PISA are used in the analysis that is the reason why the quality of education can be measured by the achievement of students via the scores on international test represented the cross-country variations in cognitive skills of the students and thereby the differences in the quality of the future labour force (Lee \& Barro, 2001). Besides, the government expenditure that placed in primary, secondary and tertiary levels is selected in relation to the country's sources of educational finance (Riddell, 1993). Figure 2 presents the framework of the network structure modeled as a three-stage process.

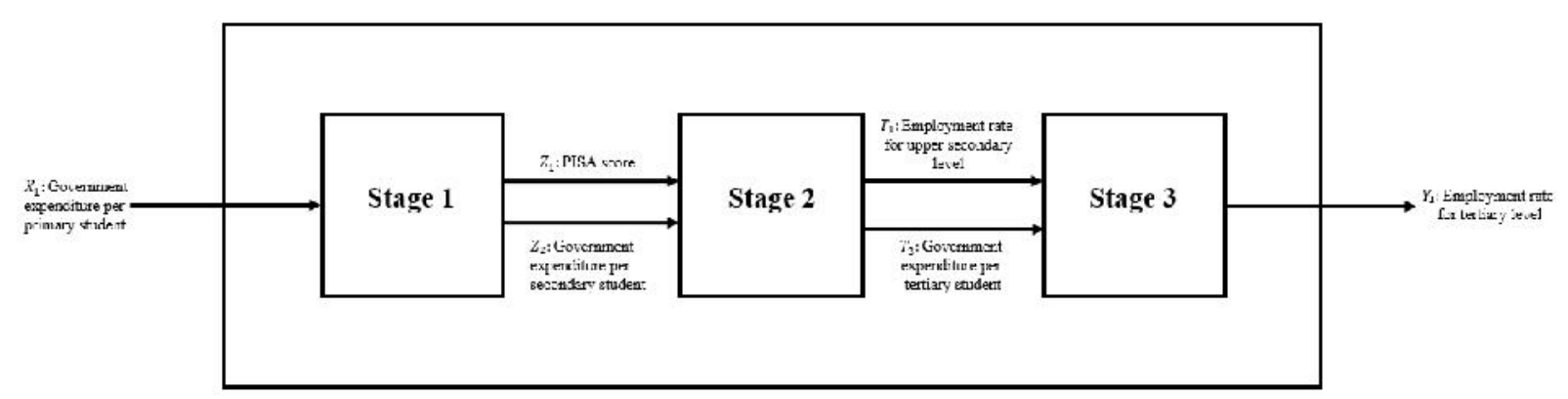

Figure 2. Relational network DEA structure for SDG 4

Table 2. Data

\begin{tabular}{|c|c|c|c|c|c|c|c|}
\hline DMU & Country & $X_{1}$ & $Z_{1}$ & $Z_{2}$ & $T_{1}$ & $T_{2}$ & $Y_{1}$ \\
\hline 1 & Australia & 18.5932 & 509.9939 & 16.7917 & 77.6700 & 22.5295 & 83.1767 \\
\hline 2 & Austria & 23.4497 & 495.0375 & 27.3519 & 75.9433 & 36.1737 & 85.4733 \\
\hline 3 & Belgium & 22.4726 & 501.9997 & 25.7987 & 72.8533 & 33.0074 & 84.4900 \\
\hline 4 & Chile & 15.0754 & 446.9561 & 15.1517 & 71.7000 & 17.3957 & 84.1950 \\
\hline 5 & Czech Republic & 15.5312 & 492.8300 & 23.5477 & 77.7067 & 21.6123 & 84.7400 \\
\hline 6 & Denmark & 25.6117 & 501.9369 & 28.2276 & 79.6433 & 44.6629 & 86.2533 \\
\hline 7 & Estonia & 21.4939 & 534.1937 & 20.1925 & 75.7733 & 27.7667 & 84.2533 \\
\hline 8 & Finland & 21.0185 & 530.6612 & 27.2000 & 73.2000 & 35.4852 & 83.3400 \\
\hline 9 & France & 18.0165 & 494.9776 & 26.8059 & 72.8867 & 35.0586 & 84.0300 \\
\hline 10 & Germany & 17.9128 & 509.1406 & 23.4938 & 79.4667 & 37.5885 & 87.9900 \\
\hline 11 & Hungary & 18.4491 & 476.7475 & 19.5469 & 71.5033 & 23.8811 & 81.6667 \\
\hline 12 & Iceland & 24.4524 & 473.2301 & 18.3453 & 87.0433 & 25.6424 & 91.2133 \\
\hline 13 & Ireland & 16.7971 & 502.5751 & 21.6000 & 67.6133 & 25.2509 & 81.1100 \\
\hline 14 & Israel & 21.4471 & 466.5528 & 16.9659 & 72.4467 & 19.4927 & 85.9100 \\
\hline 15 & Italy & 21.3017 & 480.5468 & 23.0962 & 69.8567 & 26.1989 & 78.1000 \\
\hline 16 & Korea & 23.9656 & 515.8099 & 23.3231 & 71.9867 & 13.7440 & 77.4733 \\
\hline 17 & Latvia & 31.2500 & 490.2250 & 29.6703 & 70.9233 & 22.9545 & 85.1000 \\
\hline 18 & Mexico & 14.8592 & 415.7099 & 16.4109 & 70.6100 & 40.4662 & 80.3367 \\
\hline 19 & New Zealand & 18.6102 & 513.3035 & 22.3160 & 80.9400 & 27.9934 & 86.8167 \\
\hline 20 & Norway & 19.9855 & 498.4811 & 24.3500 & 81.2633 & 38.0238 & 89.5500 \\
\hline 21 & Poland & 26.4191 & 501.4353 & 21.7531 & 66.1867 & 24.8147 & 86.0367 \\
\hline 22 & Portugal & 23.6089 & 501.1001 & 15.1691 & 77.4400 & 25.4516 & 82.2067 \\
\hline 23 & Slovak Republic & 19.4372 & 460.7749 & 18.7881 & 71.2133 & 20.7731 & 79.9067 \\
\hline 24 & Slovenia & 28.8696 & 512.8636 & 25.5421 & 69.5467 & 21.1539 & 83.8000 \\
\hline 25 & Spain & 17.7485 & 492.7861 & 22.4697 & 66.0233 & 22.6820 & 77.3800 \\
\hline 26 & Sweden & 25.3405 & 493.4224 & 24.6998 & 84.1767 & 43.4855 & 89.1367 \\
\hline 27 & Switzerland & 25.3405 & 505.5058 & 25.4500 & 81.2233 & 38.1637 & 88.1067 \\
\hline 28 & Turkey & 13.3391 & 425.4895 & 14.7689 & 61.8800 & 24.2958 & 76.4267 \\
\hline 29 & United Kingdom & 22.8298 & 509.2215 & 22.6604 & 79.5733 & 37.0920 & 84.9200 \\
\hline 30 & United States & 19.8534 & 496.2424 & 22.5901 & 68.0967 & 24.6532 & 80.5533 \\
\hline
\end{tabular}


In stage 1, government expenditure for primary level and PISA scores are taken into consideration. In stage 2 and stage 3, government expenditures, employment rates respectively for upper secondary and tertiary levels are taken into consideration. In this case, we can measure the efficiency of stage 1 of each OECD country among the set of DMUs using $X_{1}$ as input and $Z_{1}, Z_{2}$ as outputs. The efficiencies of the stage 2 can be measured using $Z_{1}, Z_{2}$ as input and $T_{1}, T_{2}$ as outputs. Similarly, the efficiencies of the stage 3 can be measured using $T_{1}, T_{2}$ as input and $Y_{1}$ as outputs. The overall efficiency is also measured using $X_{1}$ as input and $Y_{1}$ as outputs with Model (1). Table 2 presents the network structure for the implementation of the SDG 4 and the data.

\section{RESULT and FINDINGS}

As mentioned in the literature section, a number of studies have shown that there is a positive link between government expenditure on education and employment. This study reveals that the network DEA model can be used with the aim of measuring the efficiency of the OECD countries from an educational economy perspective. The overall and substages efficiencies are calculated for each country with the Model (1) and Model (2) using the GAMS code in Appendix A and Appendix B.

After running the GAMS codes, the efficiency scores and the rank of countries are shown in Table 3 and Figure 3. The ranking at the overall efficiency scores $\left(E_{k}\right)$ shows that Latvia, Slovenia and Korea at the top-three countries in terms of network structure's indicators. Additionally, Turkey, Chile and Czechia are found as the lowest three countries. Broadly speaking, the findings are verified that the developed countries in data set are carried to an upper order in the ranking. Conversely, the developing countries such as Turkey, Chile and Mexico are located at the lower in the ranking. Amazingly, Korea is located at third place notwithstanding the country is developing.

Table 3 shows that Sweden, Iceland, United Kingdom and Portugal are at the highest order of ranking in stage-1. At first look the rank of Portugal are demonstrating encouraging results. But, Portugal is one of the countries that has made the fastest progress in improving educational attainment such as PISA scores (OECD, 2012). In this context, there is no doubt that an increase in PISA scores and government expenditure for related level will lead to an enhancement in the efficiency of stage- 1 due to the impact of the output-oriented model in the analysis.

In stage-2, Slovenia has been found an efficient country with regard to indicators of the educational economy. Besides, Latvia, and Spain have an efficiency score that is very close to 1.0000. However, Iceland, Portugal, and Mexico have the lowest efficiency scores. Considering the structure of Figure 3, high investments in education accelerates the growth of countries, and the growth of the country maintains the employment rates (Domar, 1946; Landau, 1983).

In stage-3, Latvia has the highest efficiency score $\left(E_{k}=1.0000\right)$. Following this country, it is seen that Portugal and Iceland have respectively 0.9998 and 0.9726 efficiency score. The fact that those countries are in the top three can be owing to having high employment rate and budgeting high government expenditure per student. On the other hand, Czechia, France, and Ireland have respectively $0.5411,0.5983$ and 0.6066 efficiency scores. This indicates that these countries need improvement in the indicators that used for the network structure model. 
Table 3. Efficiency scores*

\begin{tabular}{llllll}
\hline DMU & Country & $E_{k}$ & $E_{k}^{1}$ & $E_{k}^{2}$ & $E_{k}^{3}$ \\
\hline 1 & Australia & $0.5305(22)$ & $0.9720(7)$ & $0.7274(26)$ & $0.7503(17)$ \\
2 & Austria & $0.6532(9)$ & $0.9401(14)$ & $0.8988(11)$ & $0.7731(14)$ \\
3 & Belgium & $0.6307(13)$ & $0.9123(20)$ & $0.9137(10)$ & $0.7566(16)$ \\
4 & Chile & $0.4269(29)$ & $0.8875(23)$ & $0.7157(27)$ & $0.6721(21)$ \\
5 & Czechia & $0.4358(28)$ & $0.9542(10)$ & $0.8441(14)$ & $0.5411(30)$ \\
6 & Denmark & $0.7074(5)$ & $0.9799(4)$ & $0.8651(13)$ & $0.8345(9)$ \\
7 & Estonia & $0.6087(14)$ & $0.9494(12)$ & $0.8266(15)$ & $0.7756(13)$ \\
8 & Finland & $0.5996(15)$ & $0.9294(17)$ & $0.9610(4)$ & $0.6713(22)$ \\
9 & France & $0.5100(23)$ & $0.9214(18)$ & $0.9252(9)$ & $0.5983(29)$ \\
10 & Germany & $0.4859(26)$ & $0.9594(9)$ & $0.8103(19)$ & $0.6250(27)$ \\
11 & Hungary & $0.5353(20)$ & $0.9150(19)$ & $0.8194(16)$ & $0.7140(18)$ \\
12 & Iceland & $0.6397(12)$ & $1.0000(1)$ & $0.6577(30)$ & $0.9726(3)$ \\
13 & Ireland & $0.4917(25)$ & $0.8758(25)$ & $0.9256(8)$ & $0.6066(28)$ \\
14 & Israel & $0.5920(16)$ & $0.8758(26)$ & $0.7649(25)$ & $0.8837(6)$ \\
15 & Italy & $0.6491(10)$ & $0.9433(13)$ & $0.8926(12)$ & $0.7709(15)$ \\
16 & Korea & $0.7357(3)$ & $0.9519(11)$ & $0.9514(5)$ & $0.8124(10)$ \\
17 & Latvia & $0.8770(1)$ & $0.8778(24)$ & $0.9991(2)$ & $1.0000(1)$ \\
18 & Mexico & $0.4382(27)$ & $0.9298(16)$ & $0.7049(28)$ & $0.6686(23)$ \\
19 & New Zealand & $0.5093(24)$ & $0.9751(5)$ & $0.8125(18)$ & $0.6428(24)$ \\
20 & Norway & $0.5327(21)$ & $0.9653(8)$ & $0.8032(20)$ & $0.6871(20)$ \\
21 & Poland & $0.7279(4)$ & $0.8096(29)$ & $0.9476(6)$ & $0.9488(4)$ \\
22 & Portugal & $0.6843(6)$ & $0.9925(3)$ & $0.6896(29)$ & $0.9998(2)$ \\
23 & Slovak Republic & $0.5784(18)$ & $0.9330(15)$ & $0.7885(22)$ & $0.7862(12)$ \\
24 & Slovenia & $0.8180(2)$ & $0.8650(27)$ & $1.0000(1)$ & $0.9457(5)$ \\
25 & Spain & $0.5449(19)$ & $0.8978(21)$ & $0.9632(3)$ & $0.6301(25)$ \\
26 & Sweden & $0.6744(8)$ & $1.0000(1)$ & $0.7784(23)$ & $0.8664(7)$ \\
27 & Switzerland & $0.6804(7)$ & $0.9740(6)$ & $0.8160(17)$ & $0.8561(8)$ \\
28 & Turkey & $0.4154(30)$ & $0.8534(28)$ & $0.7737(24)$ & $0.6291(26)$ \\
29 & United Kingdom & $0.6407(11)$ & $0.9927(2)$ & $0.8001(21)$ & $0.8067(11)$ \\
30 & United States & $0.5851(17)$ & $0.8880(22)$ & $0.9379(7)$ & $0.7025(19)$ \\
& & &
\end{tabular}

* The values in parentheses are rank values of the countries. 




Figure 3. Efficiency scores of the countries

To sum up, the reason for the high ranks of the countries is that the employment rate can be increased by the awareness of the quality education. Within this framework, these countries can enhance their efficiency score by designing educational economy policies toward strengthening the employment rate per each stage.

\section{DISCUSSION and CONCLUSION}

The government expenditure on education can be regarded as one of the most important indicators influence on increasing employment growth. On a priori grounds, it is not always possible to measure the efficiency of the countries on how government expenditure affects the employment rate. However, it is noteworthy that the evaluation of the countries as a whole in terms of educational economy for academic literature and policy-making studies. Besides, indicators such as government expenditures on education and employment rates at education levels determined by the OECD can be used directly in the evaluation of the educational performance of countries. However, these indicators used alone are not sufficient to determine the educational economy performance of a country. In this context, situations related to the different economic, social and cultural conditions of the nations at the micro level should be taken into consideration while a combination of official statistics should be used at the macro 
level. In this way, it is possible to evaluate the multi-dimensional concepts of quality education (SDG 4) together.

This paper has desired to find an answer to the question of whether the government expenditure on education affects the employment rates at ISCED education levels. To tackle this issue, we examine the educational economy efficiency of OECD countries using the relational network DEA, which is a sub-branch of the network DEA model, in order to provide support to policymakers, international education statistics users and academic studies and to determine the indicators that affect quality education. Traditional DEA models perform better than parametric methods in the performance measurement of individual decision-making units. For this reason, it is more accurate to use the traditional DEA based approaches in the research of regional and national education systems and in measuring the performance of the educational economy. However, traditional DEA models are not suitable for measuring the efficiency of substages structures because the performance of interactive substages is neglected. In contrast to traditional DEA models, the relational network DEA can present a systematic view which reflects the countries' correct rank, and provide information about the countries' positioning with regard to indicators used. This analysis shed new light on measuring the educational economy efficiency by taking into consideration indicators on the substages. In this context, we have investigated multistage efficiency scores across the OECD countries by assessing the outputs PISA science performance (stage-1), government expenditure per secondary student (stage-1), employment rate for upper secondary level (stage-2), government expenditure per tertiary student (stage-2), employment rate for tertiary level (stage-3) against inputs directly used in the education system (Government expenditure per primary student (stage-1), PISA science performance (stage-2), Government expenditure per secondary student (stage-2), employment rate for upper secondary level (stage-3), government expenditure per tertiary student (stage-3). By means of having the efficiency of the substages, it was also possible to examine the effects of the indicators used in each substages on the overall educational economy efficiency.

As a consequence of the relational network DEA model's solution, a low-efficiency score is assigned to inadequate units, namely countries, and a high-efficiency score is assigned to adequate units. This efficiency scores reflect the distance to other units in the efficient border estimated during the performance evaluation phase. Thus, the minimum proportional decrease in the inputs or the maximum proportional increase in the outputs of the efficient units can be determined. The empirical results demonstrate that the countries with high-efficiency scores are clustered around countries like Latvia, Slovenia, Korea, and Poland in both overall efficiency and the substages efficiency. In other respect, the countries with low-efficiency scores are clustered around a small number of core countries like Czechia, Mexico, Turkey, and Chile. Therefore, the current paper points out that the relational network DEA can be applied for measuring the educational economy efficiency of the countries due to the capability of providing realistic findings in the country assessment. Besides, it can be said that the relational network DEA models, which provide a scientifically objective analysis and capture the performance complexity of the units dealt with by their nature, are used as an important tool in making international comparisons of country performance in specific areas such as competitiveness, globalization, innovation, and sustainable development. Considering the efficiency scores obtained with this model, the substages efficiencies of the countries define the performance of macroeconomic indicators affecting the education economy at a disaggregated level and enables the analysis of policy areas. On the other hand, the overall efficiency scores of the countries can help determine the policy priorities by determining the extent to which the national performance expectation is met through an international comparison. In this context, network DEA models analyze economic performance beyond simple one-dimensional models that allow analysis between different areas. 


\section{ORCID}

\section{Deniz Koçak (i) https://orcid.org/0000-0002-5893-0564 \\ Hasan Türe (iD https://orcid.org/0000-0002-1975-9063}

\section{REFERENCES}

Abbott, M., \& Doucouliagos, C. (2003). The efficiency of Australian universities: a data envelopment analysis. Economics of Education Review, 22, 89 - 97. https://doi.org/10.1 016/S0272-7757(01)00068-1

Afonso, A., \& Aubyn, M. S. (2005). Non-parametric approaches to education and health efficiency in OECD countries. Journal of Applied Economics, 8, 227-246.

Afonso, A., \& Aubyn M. S. (2006). Cross-country efficiency of secondary education provision: A semi-parametric analysis with non-discretionary inputs. Economic Modelling 23, 476491.

Afonso, A., Schuknecht, L., \& Tanzi, V. (2005). Public sector efficiency: An international comparison. Public Choice, 123, 321-347.

Aristovnik, A. (2012). The impact of ICT on educational performance and its efficiency in selected EU and OECD countries: A non-parametric analysis. Available at SSRN: https://ssrn.com/abstract=2187482 or http://dx.doi.org/10.2139/ssrn.2187482

Aubyn, M. S. (2003). Evaluating efficiency in the Portuguese education sector. Economia, 26, $25-51$.

Barra, C., Lagravinese, R., \& Zotti, R. (2018). Does econometric methodology matter to rank universities? An analysis of Italian higher education system. Socio-Economic Planning Sciences, 62, 104-120.

Chen, Z., \& Wu, Y. (2007). The relationship between education and employment: A theoretical analysis and empirical test. Frontiers of Economics in China, 2 (2), 187-211. https://doi.org/10.1007/s11459-007-0010-4

Ciro, J. A., \& Garcia, A. T. (2018). Economic efficiency of public secondary education expenditure: How different are developed and developing countries?. Desarrollo Sociedad, 80, 119-154.

Domar, E. D. (1946). Capital expansion, rate of growth, and employment. Econometrica, 14 (2), 137-147.

Griggs, D., Stafford-Smith, M., Gaffney, O., Rockström, J., Öhman, M. C., Shyamsundar, P., Steffen, W., Glaser, G., Kanie, N., \& Noble, I. (2013). Policy: Sustainable development goals for people and planet. Nature, 495, 305-307.

Guironnet, J. P., \& Peypoch, N. (2018). The geographical efficiency of education and research: The ranking of U.S. universities. Socio-Economic Planning Sciences, 62, 44-55.

Gupta, S., \& Verhoeven, M., (2001). The efficiency of government expenditure experiences from Africa. Journal of Policy Modelling, 23, 433-467. https://doi.org/10.1016/S0161$\underline{\text { 8938(00)00036-3 }}$

Hanushek, E. A., \& Kimko, D. D. (2000). Schooling, labor force quality, and the growth of nations. American economic review, 90 (5), 1184-1208.

Hopkins, C., \& McKeown, R. (2002). Education for sustainable development: An international perspective. In Tilbury, D., Stevenson, R. B, Fien J. \& Schreuder, D. (Eds.), Education and Sustainability: Responding to the global challenge, Commission on Education and Communication, IUCN, Gland, Switzerland and Cambridge, UK.

Jafarov, E., \& Gunnarsson, V. (2008). Government spending on health care and education in Croatia: Efficiency and reform options. International Monetary Fund, IMF Working Paper, WP/08/136. 
Johnes, J. (2006). Data envelopment analysis and its application to the measurement of efficiency in higher education. Economics of Education Review, 25 (3), 273-288. https://doi.org/10.1016/j.econedurev.2005.02.005

Johnes, J., Portela, M., \& Thanassoulis, E. (2017). Efficiency in education. Journal of the Operational Research Society, 68, 331 - 338. https://doi.org/10.1016/j.econedurev.2005. $\underline{02.005}$

Kao, C. (2009). Efficiency decomposition in network data envelopment analysis: A relational model. European Journal of Operational Research, 192, 949-962. https://doi.org/10.1016/j.ejor.2007.10.008

Kashim, R., Kasim, M. M., \& Abd Rahman, R. (2017). Measuring efficiency of a university faculty using an extended hierarchical network dea model: A framework. Advanced Science Letters, 23 (9), 9090-9093

Landau, D. (1983). Government expenditure and economic growth: A cross-country study. Southern Economic Journal, 49 (3), 783-792.

Lavrinovicha, I., Lavrinenlo, O., \& Teivans-Treinovskis, J. (2015). Influence of education on unemployment rate and incomes of residents. Procedia Social and Behavioral Sciences, 174 (12), 3824-3831. https://doi.org/10.1016/j.sbspro.2015.01.1120

Le Blanc, D. (2015). Towards integration at last? The sustainable development goals as a network of targets. Sustainable Development, 23, 176-187. doi: 10.1002/sd.1582

Lee, J.-W., \& Barro, R. J. (2001). Schooling quality in a cross-section of countries. Economica, 68 (272), 465-488.

OECD (2012). Portugal, Country Note, Education at a Glance 2012: OECD Indicators Publishing, doi: 10.1787/eag-2012-en

Qin, X., \& Du, D. (2018). Measuring universities' R\&D performance in China's provinces: A multistage efficiency and effectiveness perspective. Journal Technology Analysis \& Strategic Management, 30(12), 1392-1408. doi: 10.1080/09537325.2018.1473849

Ramzi, S., Afonso, A. \& Ayadi, M. (2016). Assessment of efficiency in basic and secondary education in Tunisia: A regional analysis. International Journal of Educational Development, 51, 62-76.

Riddell, A. R. (1993). The evidence on public/private educational trade-offs in developing countries. International Journal of Educational Development, 13 (4), 373-386.

Ruggiero, J. (2006). Measurement error, education production and data envelopment analysis. Economics of Education Review, 25, 327 - 333. https://doi.org/10.1016/j.econedurev.20 05.03 .003

Sterling, S. (2001). Sustainable Education: Re-Visioning Learning and Change. Schumacher Briefings. Schumacher UK, CREATE Environment Centre, Seaton Road, Bristol, BS1 $6 \mathrm{XN}$, England.

Sylwester, K. (2002). Can education expenditures reduce income inequality? Economics of Education Review, 21 (1), 43-52. https://doi.org/10.1016/S0272-7757(00)00038-8

UNICEF (2016). The state of the world's children, a fair chance for every child. Available online: https://www.unicef.org/publications/files/UNICEF_SOWC_2016.pdf (9 July 20 18)

United Nations (2015). Transforming our world: The 2030 agenda for sustainable development. Available online: http://www.un.org/ga/search/view_doc.asp?symbol=A /RES/70/1\&Lang=E (5 December 2018)

United Nations (2018). Sustainable development goal 4 and its targets, Available online: https://www.un.org/sustainabledevelopment/education (10 November 2018).

Wasylenko, M., \& McGuire, T. (1985). Jobs and taxes: The effect of business climate on states' employment growth rates. National Tax Journal, 38(4), 497-511. 
Worthington, A. C. (2001). An empirical survey of frontier efficiency measurement techniques in education. Education Economics, 9 (3), 245-268. doi: 10.1080/09645290110086126

Yang, G.-L., Fukuyama, H., \& Song Y.-Y. (2018). Measuring the inefficiency of Chinese research universities based on a two-stage network DEA model. Journal of Informetrics, 12 (1), 10-30. https://doi.org/10.1016/j.joi.2017.11.002 


\section{APPENDIX}

Appendix A. GAMS code to calculate the overall efficiency

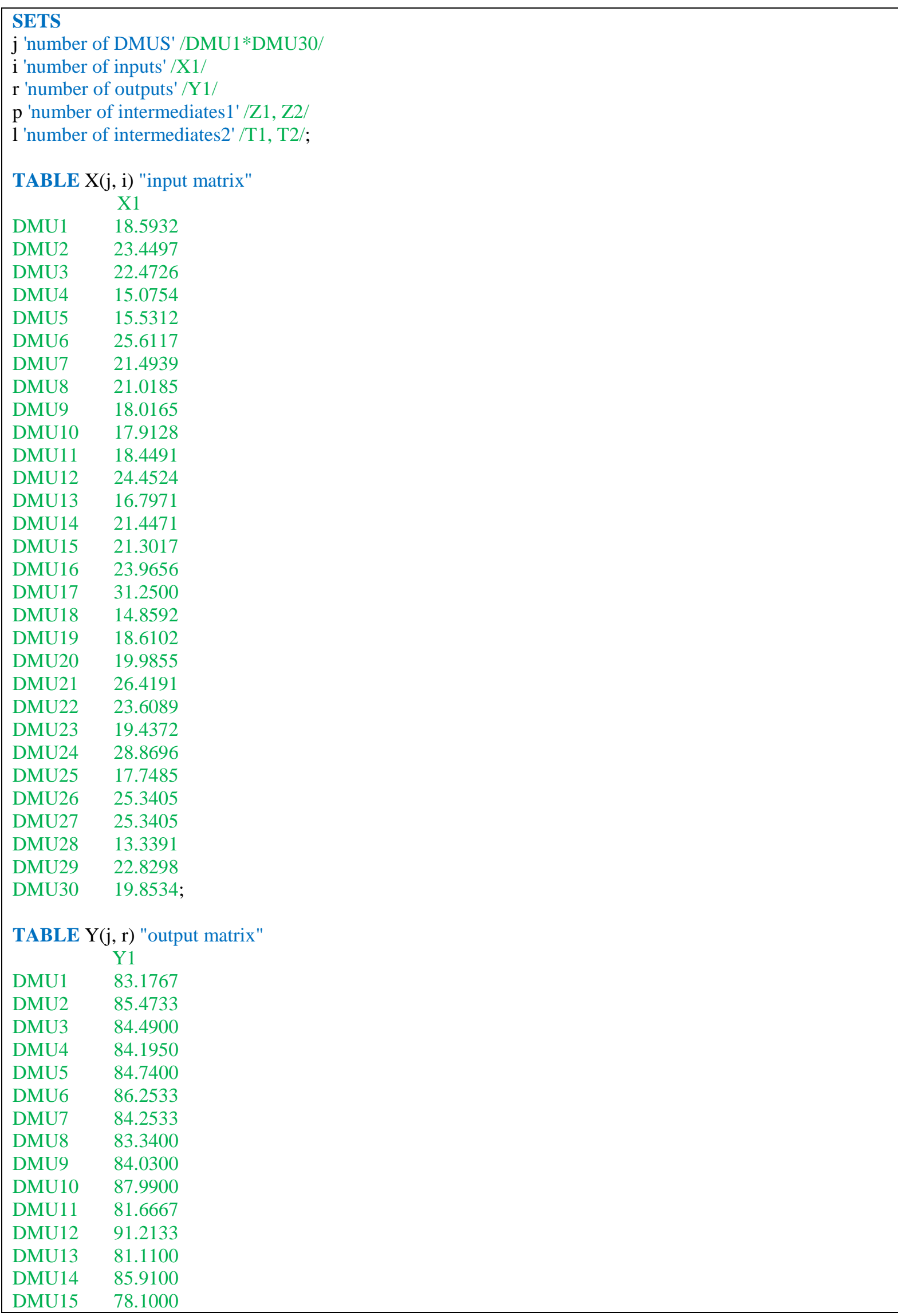




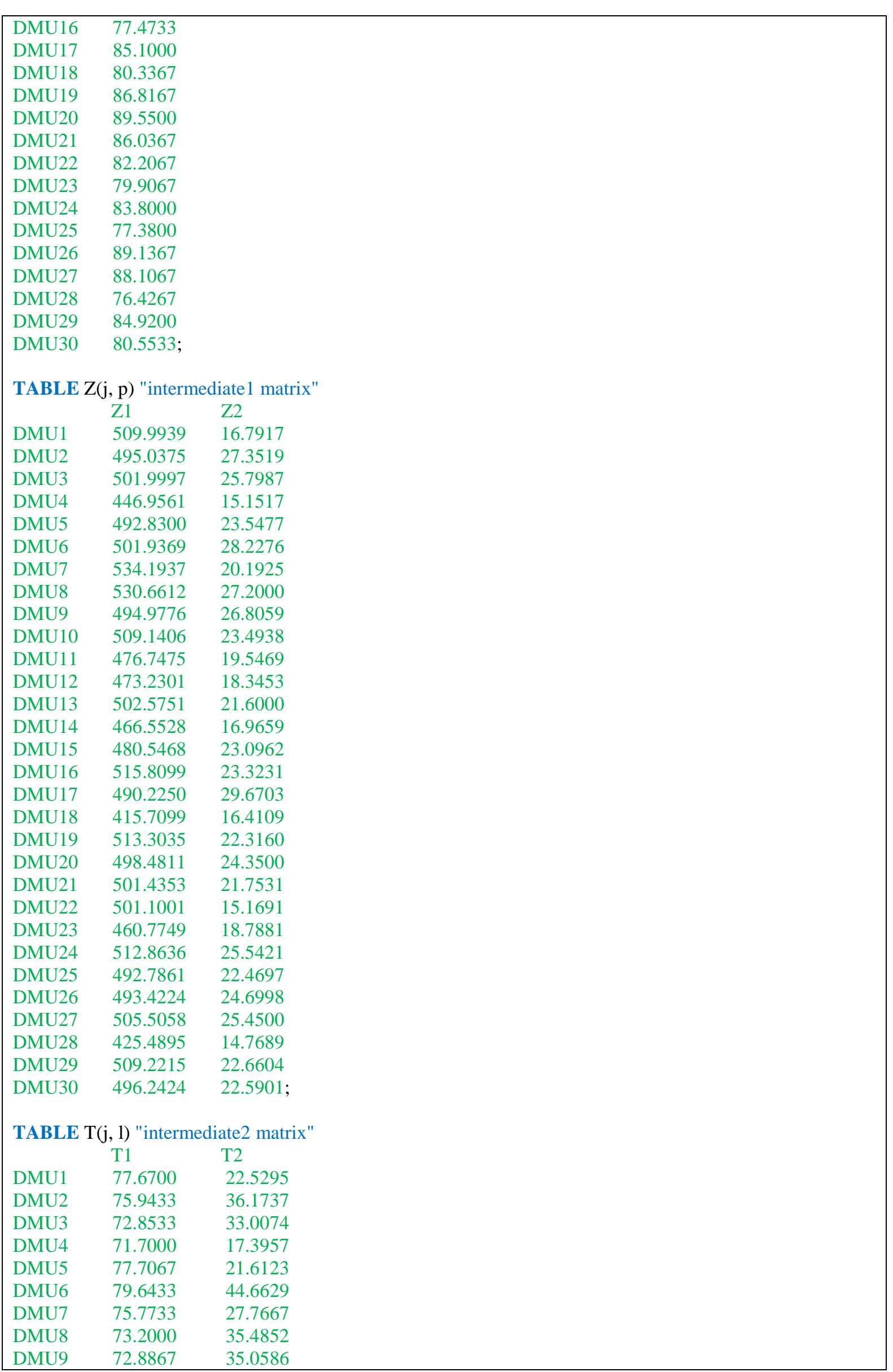




\begin{tabular}{|c|c|c|}
\hline DMU10 & 79.4667 & 37.5885 \\
\hline DMU11 & 71.5033 & 23.8811 \\
\hline DMU12 & 87.0433 & 25.6424 \\
\hline DMU13 & 67.6133 & 25.2509 \\
\hline DMU14 & 72.4467 & 19.4927 \\
\hline DMU15 & 69.8567 & 26.1989 \\
\hline DMU16 & 71.9867 & 13.7440 \\
\hline DMU17 & 70.9233 & 22.9545 \\
\hline DMU18 & 70.6100 & 40.4662 \\
\hline DMU19 & 80.9400 & 27.9934 \\
\hline DMU20 & 81.2633 & 38.0238 \\
\hline DMU21 & 66.1867 & 24.8147 \\
\hline DMU22 & 77.4400 & 25.4516 \\
\hline DMU23 & 71.2133 & 20.7731 \\
\hline DMU24 & 69.5467 & 21.1539 \\
\hline DMU25 & 66.0233 & 22.6820 \\
\hline DMU26 & 84.1767 & 43.4855 \\
\hline DMU27 & 81.2233 & 38.1637 \\
\hline DMU28 & 61.8800 & 24.2958 \\
\hline DMU29 & 79.5733 & 37.0920 \\
\hline DMU30 & 68.0967 & 24.6532; \\
\hline \multicolumn{3}{|c|}{ parameters } \\
\hline \multicolumn{3}{|c|}{ Xo(i) "input vector of DMUo" } \\
\hline \multicolumn{3}{|c|}{ Yo(r) "outputput vector of DMUo" } \\
\hline \multicolumn{3}{|c|}{ Zo(p) "intermediate1 vector of DMUo" } \\
\hline \multicolumn{3}{|c|}{ To(1) "intermediate2 vector of DMUo"; } \\
\hline \multicolumn{3}{|c|}{ variables } \\
\hline \multicolumn{3}{|c|}{ thetaall "efficiency score all" } \\
\hline \multicolumn{3}{|c|}{ v(i) "input weights" } \\
\hline \multicolumn{3}{|c|}{ u(r) "output weights" } \\
\hline \multicolumn{3}{|c|}{ w(p) "intermediate 1 weights" } \\
\hline \multicolumn{3}{|c|}{ q(1) "intermediate2 weights"; } \\
\hline \multicolumn{3}{|c|}{$\begin{array}{l}\text { free variables } \\
\text { thetaall; }\end{array}$} \\
\hline \multicolumn{3}{|c|}{ positive variables } \\
\hline \multicolumn{3}{|c|}{ v(i) } \\
\hline \multicolumn{3}{|c|}{$\mathrm{u}(\mathrm{r})$} \\
\hline \multicolumn{3}{|l|}{$\mathrm{w}(\mathrm{p})$} \\
\hline \multicolumn{3}{|l|}{$\mathrm{q}(1)$} \\
\hline \multicolumn{3}{|c|}{ equations } \\
\hline \multicolumn{3}{|c|}{ EQA } \\
\hline \multicolumn{3}{|l|}{ EQB } \\
\hline \multicolumn{3}{|l|}{ EQC } \\
\hline \multicolumn{3}{|l|}{$\begin{array}{l}\text { EQD } \\
\text { EQE }\end{array}$} \\
\hline EQE & & \\
\hline EQF & & \\
\hline EQG & & \\
\hline OBJ & & \\
\hline EQA.. S & I (i, v(i) * & ) $=\mathrm{E}=1$ \\
\hline EQB $(j)$. & $\mathrm{UM}(\mathrm{r}, \mathrm{u}(\mathrm{s}$ & $(\mathrm{j}, \mathrm{r}))-\mathrm{SUM}(\mathrm{i}, \mathrm{v}(\mathrm{i}) * \mathrm{X}(\mathrm{j}, \mathrm{i}))=\mathrm{L}=0$ \\
\hline EQC (j). & $\mathrm{UM}(1, \mathrm{q}(1$ & $(\mathrm{j}, \mathrm{l}))-\operatorname{SUM}(\mathrm{i}, \mathrm{v}(\mathrm{i}) * \mathrm{X}(\mathrm{j}, \mathrm{i}))=\mathrm{L}=0$ \\
\hline$E Q D(j) .$. & $\mathrm{JM}(\mathrm{p}, \mathrm{w}($ & $\mathrm{Z}(\mathrm{j}, \mathrm{p}))-\operatorname{SUM}(\mathrm{i}, \mathrm{v}(\mathrm{i}) * \mathrm{X}(\mathrm{j}, \mathrm{i}))=\mathrm{L}=0$ \\
\hline $\begin{array}{l}\text { EQE (j). } \\
\text { EQF (j). }\end{array}$ & $\begin{array}{l}\mathrm{UM}(\mathrm{r}, \mathrm{u}(\mathrm{r} \\
\mathrm{JM}(\mathrm{r}, \mathrm{u}(\mathrm{r}\end{array}$ & $\begin{array}{l}(\mathrm{j}, \mathrm{r}))-\operatorname{SUM}(\mathrm{p}, \mathrm{w}(\mathrm{p}) * \mathrm{Z}(\mathrm{j}, \mathrm{p}))=\mathrm{L}=0 \\
(\mathrm{j}, \mathrm{r}))-\operatorname{SUM}(1, \mathrm{q}(\mathrm{l}) * \mathrm{~T}(\mathrm{j}, \mathrm{l}))=\mathrm{L}=0\end{array}$ \\
\hline
\end{tabular}




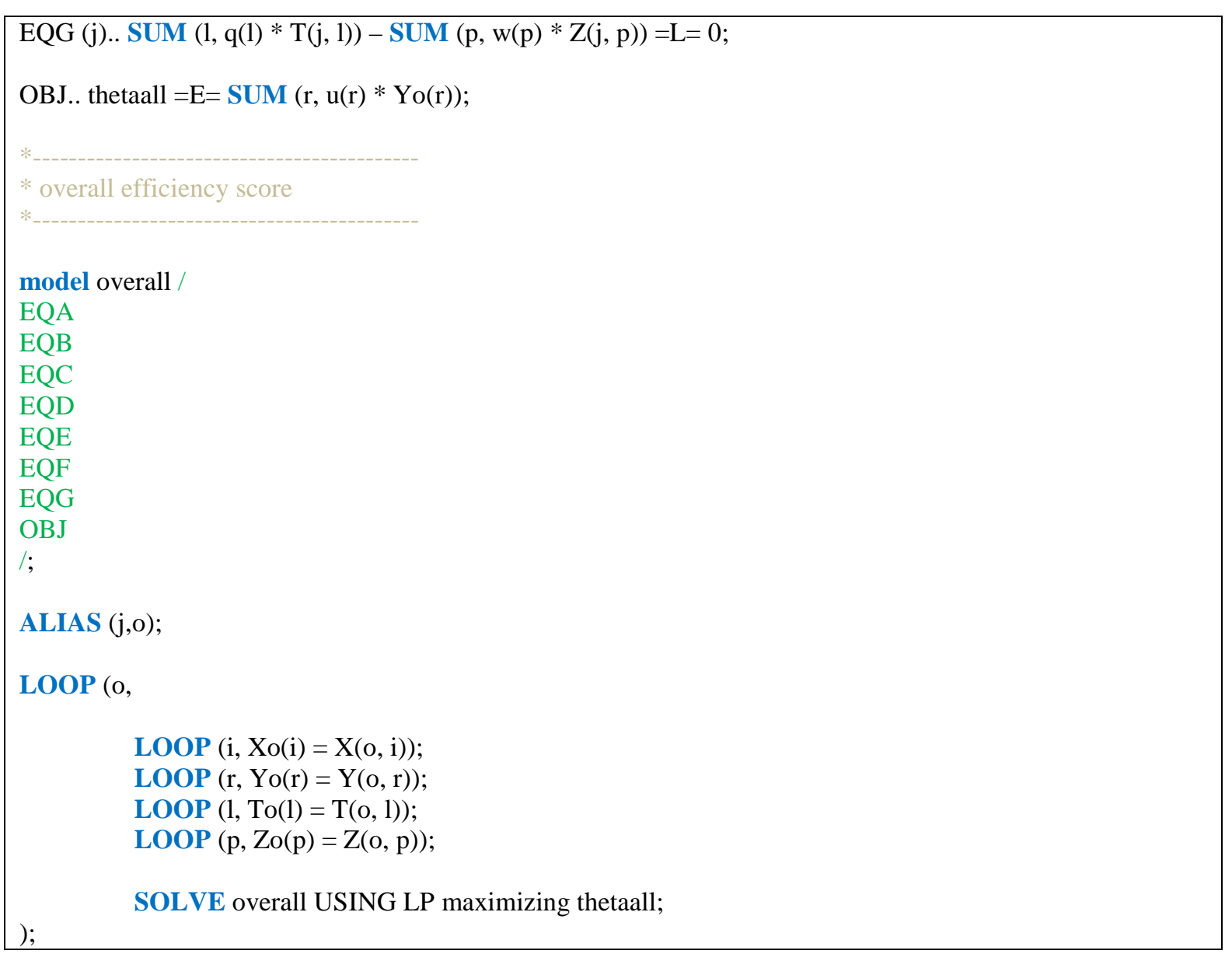

Appendix B. GAMS code to calculate the substages efficiencies

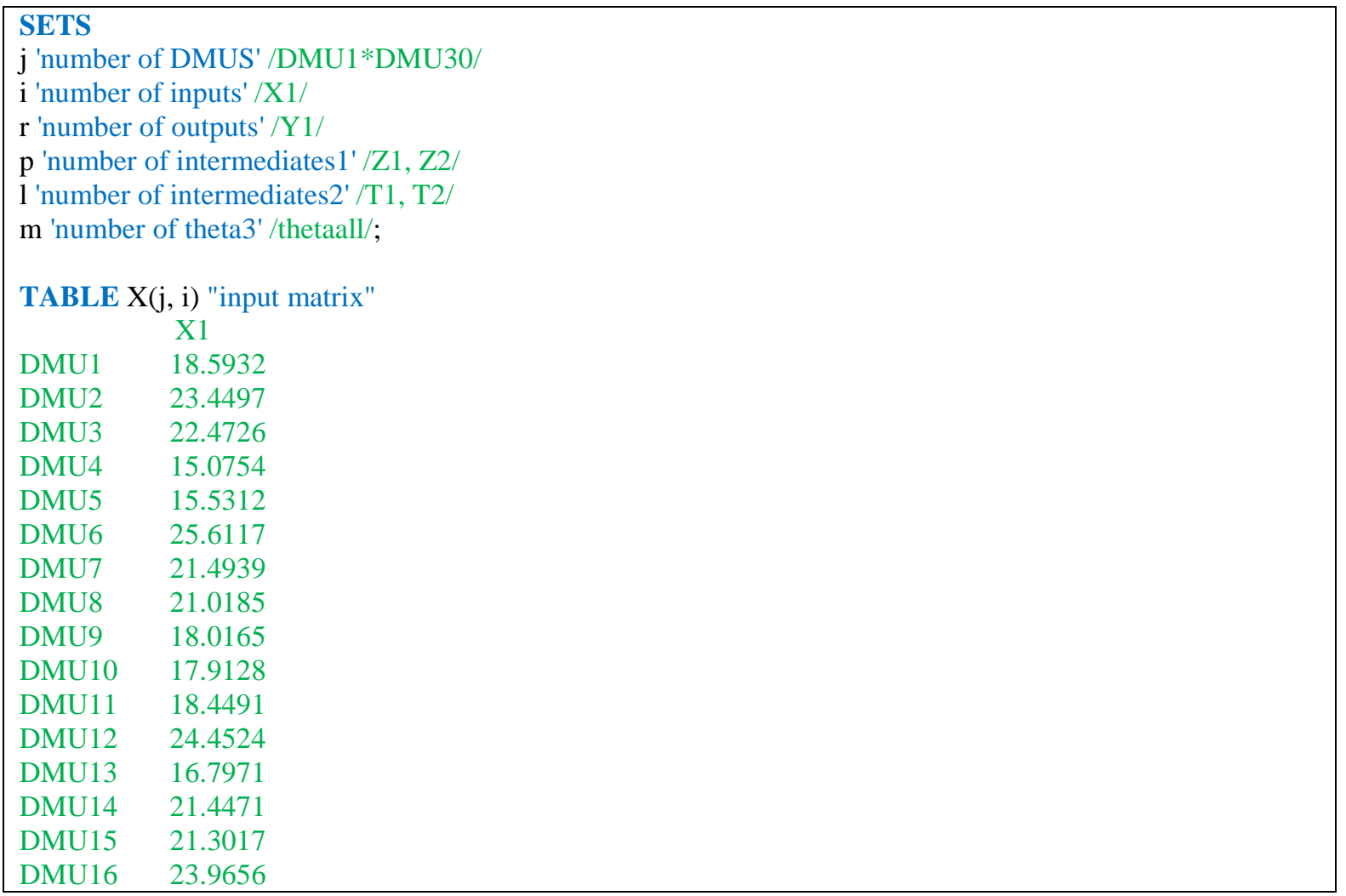




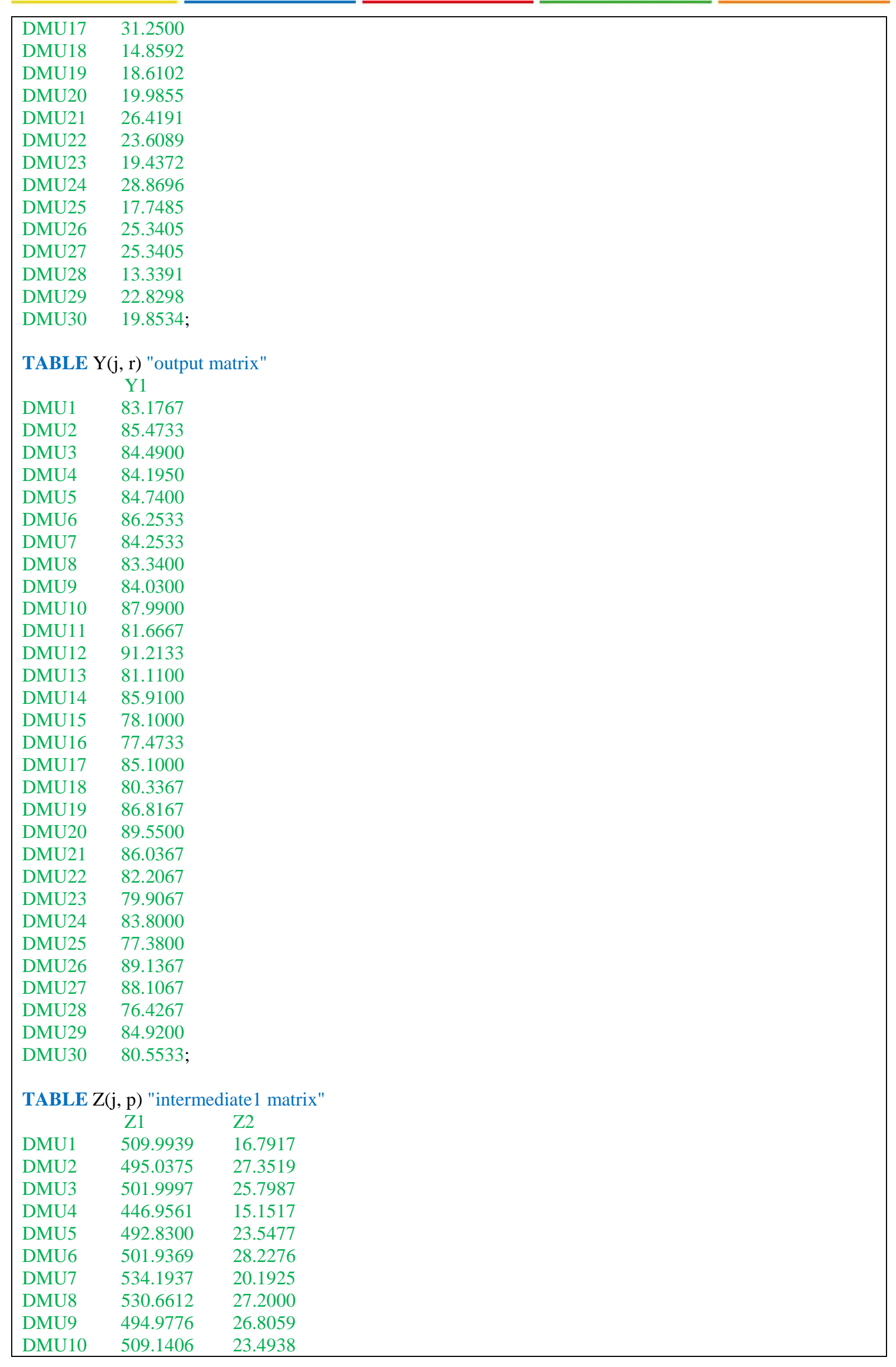




\begin{tabular}{|c|c|c|}
\hline DMU11 & 476.7475 & 19.5469 \\
\hline DMU12 & 473.2301 & 18.3453 \\
\hline DMU13 & 502.5751 & 21.6000 \\
\hline DMU14 & 466.5528 & 16.9659 \\
\hline DMU15 & 480.5468 & 23.0962 \\
\hline DMU16 & 515.8099 & 23.3231 \\
\hline DMU17 & 490.2250 & 29.6703 \\
\hline DMU18 & 415.7099 & 16.4109 \\
\hline DMU19 & 513.3035 & 22.3160 \\
\hline DMU20 & 498.4811 & 24.3500 \\
\hline DMU21 & 501.4353 & 21.7531 \\
\hline DMU22 & 501.1001 & 15.1691 \\
\hline DMU23 & 460.7749 & 18.7881 \\
\hline DMU24 & 512.8636 & 25.5421 \\
\hline DMU25 & 492.7861 & 22.4697 \\
\hline DMU26 & 493.4224 & 24.6998 \\
\hline DMU27 & 505.5058 & 25.4500 \\
\hline DMU28 & 425.4895 & 14.7689 \\
\hline DMU29 & 509.2215 & 22.6604 \\
\hline DMU30 & 496.2424 & 22.5901 \\
\hline \multicolumn{3}{|c|}{ TABLE T(j, l) "intermediate2 matrix" } \\
\hline & $\mathrm{T} 1$ & $\mathrm{~T} 2$ \\
\hline DMU1 & 77.6700 & 22.5295 \\
\hline DMU2 & 75.9433 & 36.1737 \\
\hline DMU3 & 72.8533 & 33.0074 \\
\hline DMU4 & 71.7000 & 17.3957 \\
\hline DMU5 & 77.7067 & 21.6123 \\
\hline DMU6 & 79.6433 & 44.6629 \\
\hline DMU7 & 75.7733 & 27.7667 \\
\hline DMU8 & 73.2000 & 35.4852 \\
\hline DMU9 & 72.8867 & 35.0586 \\
\hline DMU10 & 79.4667 & 37.5885 \\
\hline DMU11 & 71.5033 & 23.8811 \\
\hline DMU12 & 87.0433 & 25.6424 \\
\hline DMU13 & 67.6133 & 25.2509 \\
\hline DMU14 & 72.4467 & 19.4927 \\
\hline DMU15 & 69.8567 & 26.1989 \\
\hline DMU16 & 71.9867 & 13.7440 \\
\hline DMU17 & 70.9233 & 22.9545 \\
\hline DMU18 & 70.6100 & 40.4662 \\
\hline DMU19 & 80.9400 & 27.9934 \\
\hline DMU20 & 81.2633 & 38.0238 \\
\hline DMU21 & 66.1867 & 24.8147 \\
\hline DMU22 & 77.4400 & 25.4516 \\
\hline DMU23 & 71.2133 & 20.7731 \\
\hline DMU24 & 69.5467 & 21.1539 \\
\hline DMU25 & 66.0233 & 22.6820 \\
\hline DMU26 & 84.1767 & 43.4855 \\
\hline DMU27 & 81.2233 & 38.1637 \\
\hline DMU28 & 61.8800 & 24.2958 \\
\hline DMU29 & 79.5733 & 37.0920 \\
\hline DMU30 & 68.0967 & 24.6532 \\
\hline \multicolumn{3}{|c|}{$\begin{array}{l}\text { TABLE thetaall }(\mathrm{j}, \mathrm{m}) \text { "efficiency score matrix" } \\
\text { thetaall }\end{array}$} \\
\hline DMU1 & 0.0538 & \\
\hline DMU2 & 0.0426 & \\
\hline DMU3 & 0.0445 & \\
\hline DMU4 & 0.0663 & \\
\hline
\end{tabular}




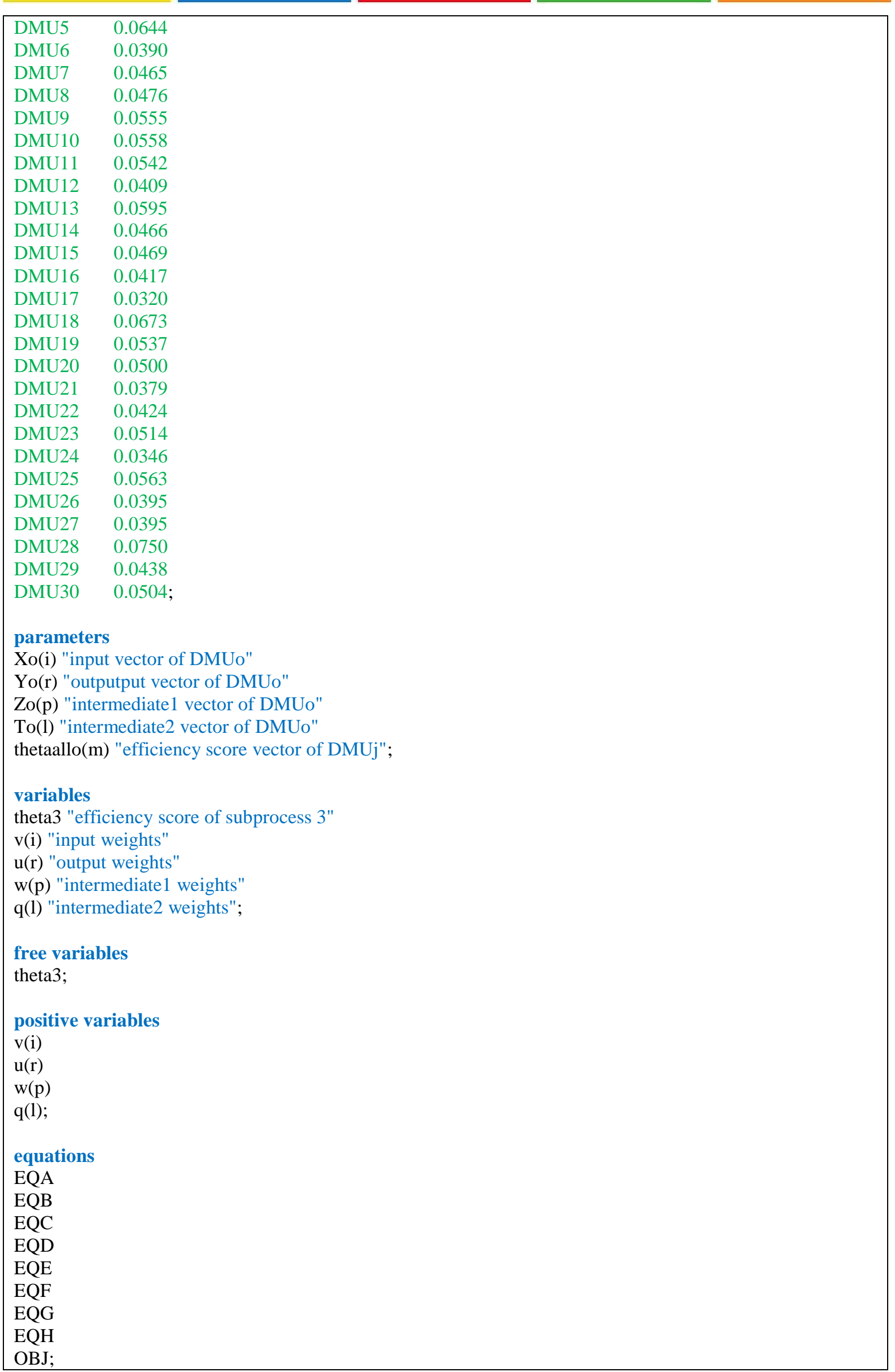


EQA..SUM $(\mathrm{p}, \mathrm{w}(\mathrm{p}) * \mathrm{Zo}(\mathrm{p}))=\mathrm{E}=1$;

EQB (m).. SUM (r, u(r) * Yo(r)) - (thetaallo(m) * SUM (i, v(i) * Xo(i))) $=\mathrm{E}=0$;

EQC (j).. SUM (r, u(r) * Y(j, r)) - SUM (i, v(i) * X(j, i)) $=\mathrm{L}=0$;

EQD (j).. SUM (l, q(l) * T(j, l)) - SUM (i, v(i) * X(j, i)) $=\mathrm{L}=0$;

$\operatorname{EQE}(j) .$. SUM (p, w(p) * Z(j, p)) - SUM (i, v(i) * X(j, i)) $=\mathrm{L}=0$;

$\operatorname{EQF}(j) . . S U M(r, u(r) * Y(j, r))-\operatorname{SUM}(1, q(1) * T(j, l))=L=0$

EQG (j).. SUM (r, u(r) * Y(j, r)) - SUM (p, w(p) * Z(j, p)) =L=0;

EQH (j).. SUM (l, q(l) * T(j, l) ) - SUM (p, w(p) * Z(j, p)) $=\mathrm{L}=0$;

OBJ.. theta3 =E= SUM $(r, \mathrm{u}(\mathrm{r}) * \mathrm{Yo}(\mathrm{r}))$;

* subprocess3 efficiency score

model subprocess3 /

EQA

EQB

EQC

EQD

EQE

EQF

EQG

$\mathrm{EQH}$

OBJ

/;

$\operatorname{ALIAS}(\mathrm{j}, \mathrm{o})$;

LOOP (o,

$\operatorname{LOOP}(\mathrm{i}, \mathrm{Xo}(\mathrm{i})=\mathrm{X}(\mathrm{o}, \mathrm{i}))$;

$\operatorname{LOOP}(r, \operatorname{Yo}(r)=\mathrm{Y}(\mathrm{o}, \mathrm{r}))$;

$\operatorname{LOOP}(1, \operatorname{To}(1)=\mathrm{T}(\mathrm{o}, \mathrm{l}))$;

LOOP (p, Zo(p) = Z(o, p));

LOOP $(\mathrm{m}$, thetaallo $(\mathrm{m})=$ thetaall $(\mathrm{o}, \mathrm{m}))$;

SOLVE subprocess2 USING LP maximizing theta3;

) 